Court of Injustice 
This page intentionally left blank 


\section{Court of Injustice}

Law Without Recognition in U.S. Immigration

J.C. Salyer

Stanford University Press

Stanford, California 
Stanford University Press

Stanford, California

(C) 2020 by the Board of Trustees of the Leland Stanford Junior University.

All rights reserved.

No part of this book may be reproduced or transmitted in any form or by any means, electronic or mechanical, including photocopying and recording, or in any information storage or retrieval system without the prior written permission of Stanford University Press.

Printed in the United States of America on acid-free, archival-quality paper

Library of Congress Cataloging-in-Publication Data is available on request.

ISBN: 978-1-5036-1140-5 (cloth)

ISBN: 978-1-5036-1248-8 (paperback)

ISBN: 978-1-5036-1249-5 (electronic)

Cover design: Michel Vrana

Typeset by Motto Publishing Services in 10/14 Minion Pro 
For Paige West 
This page intentionally left blank 